\title{
Living and thinking the event
}

The question of 'what comes after postmodernism' is rather modern at its heart and draws on a linear conceptualization of time that postmodernism has tried to challenge within different disciplinary contexts. Postmodernism has indeed created conditions of possibility for making trouble in our habitual modes of seeing, understanding and knowing, but it has also created its own archive of knowledges, authors and concepts, its own 'order of things'. My question therefore is not about 'what after', but 'what now'?

The question of 'what is our present today' is challenging, since the 'now' of our inquiries has already become past even before the question has been raised. And yet it is our inability to see, let alone grasp or address unfolding events that postmodernism has made us aware of. It is therefore in the lacuna of facing 'the event' that we find ourselves today as thinkers, political actors, educators. Acting and thinking in the remains -or shall we say the ruins-of postmodernism, the time has come to grapple with 'the untimely', align with the rhythms of the cosmos we thought we had understood and let ourselves drift in the processes within which 'events' emerge.

It is 'the event' that I therefore find at the heart of current educational theory and praxis. How can we perceive fleeting ruptures, unexpected uprisings, unforeseeable encounters and how can we include them in the toolboxes of our inquiries and analytical practices in education and beyond? Moreover, what does it mean to think and act with 'the event'? What are its epistemological conditions of possibility, as well as its ethico-political effects? Can we imagine event related research methodologies? These are some of the challenges emerging from such inquiries, which have already started mapping new planes of consistency.

From my situated position of knowing and understanding (see Haraway 1988), new materialism genealogies and methodologies are in the process of becoming such a plane of consistency, a theoretical, epistemological, methodological and political 'assemblage' for knowing and living with the event. Putting the question of 'how matter comes to matter' (Barad 2007) at the heart of its inquiries, 'the new 
materialisms assemblage', as I want to call it, traces and maps its genealogies, but also charts its 'lines of flight' (Deleuze and Guattari 1988). Excavating neomaterialism genealogies is crucial in this process, otherwise neo-materialist knowledges and practices run the risk of forgetting, which is both epistemically and politically dangerous. We have already seen symptoms of oblivion in this newly emerging assemblage (see Braidotti 2013). Foucault's archaeological method is a very useful tool here since it allows for shadowed and marginalized figures, schemas and concepts to be discerned, reread and rewritten-an educational archaeological project par excellence. (Foucault 1989) It is actually from the archaeological site that novel insights and approaches can emerge, as 'lines of flight' in the project of intra-acting with events.

\section{References}

Barad, Karen. 2007. Meeting the Universe Halfway: Quantum Physics and the Entanglement of Matter and Meaning. Durham: Duke University Press.

Braidotti, Rosi. 2013. The Posthyman. Cambridge: Polity Press.

Deleuze, Gilles and Guattari, Felix. 1988. [1980] A Thousand Plateaus: Capitalism and Schizophrenia, translated by Brian Massumi. London: The Athlone Press. Foucault, Michel.1989. [1969] The Archaeology of Knowledge. Translated by Alan Sheridan. London and New York: Routledge.

Haraway, Dona. 1988. 'Situated Knowledges: The Science Question in Feminism and the Privilege of Partial Perspective. Feminist Studies 14 (3), 575-599.

Maria Tamboukou, University of East London, UK e-mail: mariatamboukou@gmail.com 